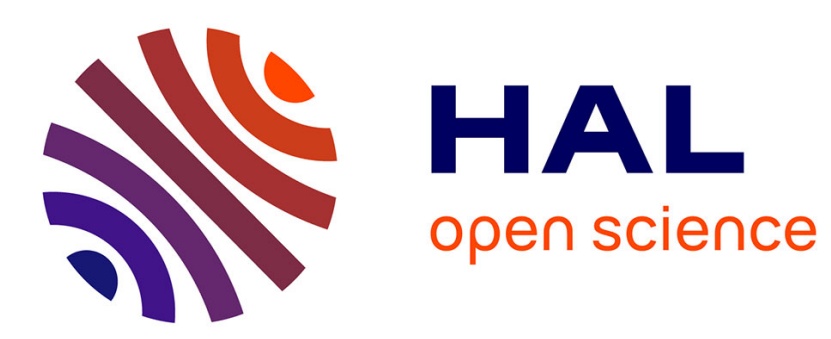

\title{
Impact of financial crises on poverty in developing world: an empirical approach
}

Zlatko Nikoloski

\section{To cite this version:}

Zlatko Nikoloski. Impact of financial crises on poverty in developing world: an empirical approach. The Journal of Development Studies, 2011, 47 (11), pp.1757-1779. 10.1080/00220388.2011.561329 . hal-00752505

\section{HAL Id: hal-00752505 \\ https://hal.science/hal-00752505}

Submitted on 16 Nov 2012

HAL is a multi-disciplinary open access archive for the deposit and dissemination of scientific research documents, whether they are published or not. The documents may come from teaching and research institutions in France or abroad, or from public or private research centers.
L'archive ouverte pluridisciplinaire HAL, est destinée au dépôt et à la diffusion de documents scientifiques de niveau recherche, publiés ou non, émanant des établissements d'enseignement et de recherche français ou étrangers, des laboratoires publics ou privés. 


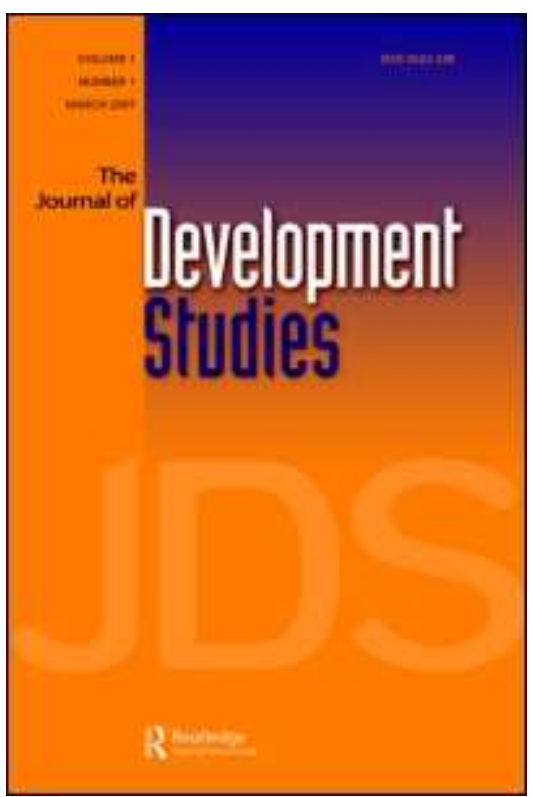

Impact of financial crises on poverty in developing world: an empirical approach

\begin{tabular}{|r|l|}
\hline Journal: & Journal of Development Studies \\
\hline Manuscript ID: & FJDS-2010-Mar-0055.R3 \\
\hline Manuscript Type: & Original Manuscripts \\
\hline Keywords: & $\begin{array}{l}\text { Debt < Economics, Economic development < Economics, } \\
\text { Developing < Geographical Area }\end{array}$ \\
\hline \multicolumn{2}{|c}{} \\
\hline
\end{tabular}

\section{SCHOLARONE ${ }^{\text {tw }}$ \\ Manuscripts}


"Impact of financial crises on poverty in developing world: an empirical approach"

\begin{abstract}
This paper adopts a cross-country perspective to analyze the short term effects of currency, banking and debt crises on the poverty headcount ratio and the poverty gap (as measured by the World Bank), employing multivariate fixed effects panel data analysis. The findings suggest that currency crises most significantly exacerbate both the incidence and depth of poverty in the short run. Banking crises are associated with an increase in the depth of poverty but not the incidence while there is no direct effect of sovereign debt crises. Given the low level of significance, the results are far from conclusive and offer only partial indications of the crises-poverty nexus.
\end{abstract}

Keywords: poverty, currency crises, banking crises, debt crises, developing countries 


\section{Introduction}

The current global financial crisis, which has evolved into a global financial and economic crisis, is another reminder of the effect of financial (and economic) crises on poverty. According to World Bank (2009), this crisis will push some 35 million more people in the Europe and Central Asia region below the poverty line. This financial crisis has renewed the interest among researchers on the relationship between financial crises and poverty and the channels through which the two variables are connected. In this spirit, this paper empirically estimates the relationship between financial crises (disaggregated into banking, currency and debt crises) and poverty in the developing world.

We posit that different types of financial crises have potentially different impact upon measures of poverty. Hence, this paper is distinct from most of the available crosscountry studies that deal with the impact of financial crises on selected macroeconomic variables, as they tend to use the term financial crises as a synonym for a currency crisis (Baldacci et al., 2002) or as a synonym for a banking crisis (Cecchetti et al., 2009) ${ }^{1}$. Moreover, our paper represents the first attempt to comprehensively estimate the impact of disaggregated financial crises on poverty while giving equal weights to the banking, currency and sovereign debt crises. In doing so, we rely on a dataset comprehending 90 low and middle income countries. Our research endeavour was also facilitated by a new dataset on financial crises (Laeven and Valencia, 2008). Finally, methodologically we employed panel fixed effects.

Any cross-country study of this nature however comes with caveats attached. First, poverty is experienced at the level of the individual. Additionally, cross country studies of poverty throw up myriad data, survey and measurement complications, including issues of income versus consumption, in-kind income, informal income, equivalence scales, regional price variations and so on. Thus, although micro data can shed more light on individual transmission mechanisms, the cross-country approach is not without its own advantages. By analyzing over a longer time period, purging the country-specific effects and by focusing on within-group variation, a cross country study can reveal much about the general forces linking macro events, such as financial crises, and poverty. In exploring these links our specifications are robust to the inclusion of additional macroeconomic variables as well as to a range of lags of the independent variables.

To date there have been only a few cross-country studies that deal with the impact of financial crises on poverty. Baldacci et al. (2002) estimate the effect of currency crises on poverty for a selected sample of emerging economies. While noting their small sample size as an important caveat they find that financial crises are bad for poverty and income inequality. Cline (2002) also makes an attempt to estimate the effects of the financial crises (mainly currency and balance of payments crises) that happened in the 1990s. Although his study is limited to only eight emerging market economies, he finds that the crises were significantly damaging to the poor. However, the impact of the crisis on levels of poverty was different depending on how a particular country dealt with the problem at hand. What emerges from this fledgling research is a consensus that, 
inevitably, crises matter for aggregate welfare and yet, constrained by data availability and quality, a comprehensive and systematic study of the aggregate relationship between poverty and crises remains elusive.

Our paper is organized as follows: in section II we account for the main macro channels through which financial crises affect poverty, while in section III we take stock of the empirical literature that has been focused on examining the links between the two variables. In section IV we present the data as well as some basic stylized facts, while section $\mathrm{V}$ contains the econometric methodology, results, and discussion and robustness checks. Section VI concludes.

\section{How financial crises impact on poverty}

\section{Slump in economic activity}

A slump in economic activity is the main indirect channel through which financial crises may impact upon poverty. Most of the extant research (Ravallion, 2001; Cline, 2002), has been focused on determining the "poverty elasticity" of growth, i.e. to what extent incomes of the poor people rise with growth (and to what extent they fall with contraction), finding that for every one percent increase in the mean income, the percentage of people living in absolute poverty decreases by 2.5 percent $^{2}$. We do argue, however, that financial crises have an additional and independent impact on levels and depth of poverty - something that we explore at the end of this section ${ }^{3}$.

\section{Decrease in earnings and labour market implications}

An occurrence of a financial crisis puts pressures on informal sector workers and changes the sectoral composition of employment, which in turn may exacerbate poverty levels. Financial crises lead to a fall in earnings of both formal and informal sector workers due to job losses in the formal sector and reduced demand for services in the informal sector. It has been previously shown that the entry of unemployed formal-sector workers into the informal sector puts additional pressure on the informal labour market, resulting in an increase in levels of poverty (Bourguignon and Morrisson, 1992; Morley, 1995; Walton and Manuyelan, 1998; Lustig and Walton, 1998).

In addition, an occurrence of financial crises increases levels of unemployment and decreases real wages. Fallon and Lucas (2002), for example, cited the example of worsening unemployment in Korea following the Asian crisis. More importantly, however, the effects of the crisis were effected through decrease of wages rather than changes in the levels of employment. For example, in Indonesia and Turkey, inflation dramatically undermined manufacturing wages: real wages fell 44 percent in Indonesia and 31 percent in Turkey in a single year. In Malaysia, real wages declined only slightly in 1998 but the effect was intensified because the decline followed a period of high real wage growth.

Relative price change 
After currency depreciation, the price of tradables (relative to non-tradables) rises, leading to a fall in earnings for those employed in the non-tradables sector. At the same time, there may be an increase in the demand for exports and consequently, employment and earning in the sectors producing exportables increase, thereby offsetting some of the losses due to the decline in GDP. Furthermore, the exchange rate may influence the price of imported food, increasing domestic food prices. This increase, in turn, hurts poor individuals and households that are net consumers of food (Baldacci et al., 2002).

In general, currency and debt crises are associated with hyperinflation, which has been shown numerous times to hurt the poor much more than the middle or the upper classes (Easterly and Fischer, 2000). As poor people spend most of their incomes on consumption, surging prices hurt their budgets thus forcing them to spend more money on consumption or to curtail their consumption patterns. Evidence from other contexts indicates that the poor may be less able to smooth consumption (Fallon and Lucas, 2002), resulting in declines in consumption with repercussions on long-term nutrition and health.

\section{Financial channel}

Financial crises could also impact upon poverty through the financial channel (Guillaumont-Jeanneney and Kpodar, 2011). According to Agenor (2002), the poor often lack the means to protect themselves from adverse income and employment shocks. They lack assets, such as bank deposits and land, and often have no direct access to credit markets (or face prohibitive borrowing costs when they do), to smooth the impact of these shocks (Fallon and Lucas 2002; Morduch, 1995). For those near the poverty threshold, borrowing to smooth consumption becomes even more expensive due to rising interest rates (Cecchetti et al, 2009). In these conditions, many families turn to less formal sources for borrowing funds, though there is little evidence on the impact of crises on such borrowing. A recent survey found that deposits to microfinance institutions continued to rise during the East Asian crisis, possibly because they were sounder institutions and rural savers were shifting out of smaller rural banks (Atinc and Walton, 1999). This could imply easier access to credit from such sources during a crisis, though recent evidence raises serious questions about whether microcredit institutions actually lend to poorer households (Rai, Topa and Amin, 1999). However, microcredit has played a limited role.

\section{Fiscal retrenchment and spending on health, social services and education}

Spending cuts affect the volume of publicly provided critical social services, including social assistance outlays, and limit the access of the poor to these services at a time when their incomes are declining (Lanjouw and Ravallion, 1999). Agenor (2002) argues that indirect sources of income and public transfers may decline during crises because during such episodes the ability of relatives or communities to engage in income redistribution may be reduced and government may be forced to drastically adjust their fiscal account with across-the-board cuts in expenditure. The public expenditure fell in absolute terms during the Asian crisis. In Thailand, for example, the long-term implications of health 
spending cuts for the AIDS epidemic raised concerns (Lucas and Fallon, 2002). In Mexico, public spending on health and labour declined 11.6 percent in real terms in 1995 and by a further 5 percent in 1996, though these cuts were less deep than overall cuts in social spending (Lustig, 2000).

Although the public spending in most of the countries in crises fell, they still kept some sizeable level of social safety nets in order to shelter the poor. In Mexico, the government shifted resources out of other anti-poverty programs to a short-term employment program in 1995, creating an estimated half a million jobs. Some 70 percent of these jobs were in rural areas and paid about 80 percent of the minimum wage (Lustig, 2000). Similar social safety nets were introduced in other Latin American countries (Argentina and Ecuador), as well as in Russia during the financial crisis from 1998.

\section{How different financial crises impact the levels of poverty}

Banking crises are expected to be associated with increases in the incidence and depth of poverty. As indicated by Baldacci et al. (2002), banking crises erode savings and deposits and are associated with changes in assets and real estate prices as well as changes in interest rates. In certain instances, banking crises put further strain on the financial system and on the ability of poor people to borrow money for the purpose of consumption smoothing (Lucas and Fallon, 2002). However, given that most poor people are on the fringes of the banking systems (and are sometimes sheltered by microcredit institutions during periods of crises), the direct impact of the banking crises should be limited in magnitude.

Currency crises are also expected to increase the depth and incidence of poverty. Almost all currency crises are accompanied by relative price changes (especially of food), which as argued above, hurts the poor disproportionately more than the rich. Currency crises are also accompanied by a slowdown in economic activity and with pressures on the labour markets that further exacerbate the conditions of the poor (Baldacci et al., 2002).

Although debt crises may not have a direct impact on poverty, sovereign debt crises are expected to increase levels of poverty indirectly via some of the channels suggested above (for example, a debt crisis could force a government to curtail its public spending $)^{4}$. In some cases, however, a debt default could free up some additional funds that could be targeted towards helping the poor especially in periods of crisis (Cecchetti et al., 2009), thus acting in an opposite direction to some of the other financial crises.

\section{The Empirical literature}

\section{Individual country studies}

Most of the empirical evidence on the impact of financial crises on poverty emerges from country level studies. In the case of Indonesia, Suryahadi and Sumarto (2003) find that poverty after the crisis rose by about 70 percent, mainly driven by the increase in the poverty gap. Particular increases were registered among the chronic poor, who suffered 
from increasing vulnerability to poverty. As a result, the proportion of the total vulnerable group jumped from less than one-fifth of the population before the crisis to more than one-third after the crisis (Said and Widyanti, 2002). Zin (2002) analyzed the impact of the financial crisis on poverty and inequality in Malaysia and as in previous studies found that rural households were hurt less than urban ones. However, the process of recovery of urban households was smoother than that of rural ones. Natenuj (2002) presents a similar account of the impact of the Asian financial crisis on poverty and inequality in Thailand. She argues that, as the economy slid into recession, most of the benefits achieved in the previous decade were washed away, with serious repercussions on the poor. As in the case of other Asian countries, the ultra poor were hurt the most during the crisis. Similar widening of poverty rates was registered in China (Chen and Wang, 2002).

The World Bank's rich database on poverty assessment studies proves useful when studying the impact of the financial crises on poverty rates in Latin America. The 2002 crisis in Argentina increased poverty rates from 37 to 58 percent. In addition, the income distribution worsened suggesting that lower socio-economic strata suffered more than the rest of the population (World Bank, 2003). In Ecuador, in addition to an increase in poverty, worsening of health and education outcomes was reported. Both governments responded with significant increases in social safety nets (World Bank, 2000).

Lokshin and Ravallion (2000), examining the welfare effects of the 1998 financial crisis in Russia, find that it was not felt only by those poor prior to 1998 but impacted upon individuals across the income distribution. According to them, the welfare effects were "on balance, poverty reducing", driven largely by effective welfare targeting. Offering a counter-view, Lokshin and Yemtsov (2004) argue that the formal social safety net was of little value for most Russians. Skoufias (2003) focuses more on the ways in which individual families coped with the crises and he finds that certain actions such as reduction of non-food expenditure acted as complements to the standard insurance strategies. Gerry and Li (2010) report that married individuals living in small households, with educated heads in urban environment, weathered the crisis better. Similarly to Lokshin and Yemtsov (2004) they find that outside of pension payments, the formal social safety net did not facilitate consumption smoothing, thus heightening the importance of informal coping institutions, principally in the form of increased home production.

\section{Cross - country studies}

The availability of cross country studies that analyze the impact of crises on poverty is limited. Baldacci et al. (2002) is the best known study that analyzes the impact of financial crises on poverty and inequality. The general finding is that the financial crises increased the incidence of poverty and inequality in their sample of emerging countries. The authors however, attach two caveats to their paper: (i) limited number of countries (as they focus on a handful of emerging economies); and (ii) low number of data points which drives the magnitude and significance of coefficients. 


\section{Data and stylized facts}

\section{Data}

Data on poverty comes from the World Development Indicators. We use four measures of poverty: poverty headcount ratio at 1.25 USD a day, poverty gap at 1.25 USD a day, poverty headcount ratio at 2 USD a day and poverty gap at 2 USD a day ${ }^{5}$. Data on banking, currency and debt crisis comes from Laeven and Valencia (2008), which consists of dummy variables for each of the three trypes of crisis which take the value of 1 for the year when a crisis happens and 0 otherwise. A more detailed description of the data is provided in online Appendix 1.

When we define the crises, it is important to note that this is the first attempt to analyze the disaggregated effects of individual financial crises on the level and depth of poverty. Previous studies have used the term financial crisis as a synonym for banking crisis (Cecchetti et al., 2009) or currency crisis (Baldacci et al., 2002).

\section{Basic stylized facts}

The basic relationship between the financial crises and poverty variables is illustrated in Table 1. The main observations are: (i) all poverty indicators jumped by at least a couple of percentage points following a currency crisis; (ii) poverty indicators increased following a debt crisis; (iii) the observations are mixed vis-à-vis banking crises - while the relative poverty headcount ratio jumped by one percentage point, the absolute poverty headcount ratio and the poverty gap measures dropped.

\section{[TABLE 1 ABOUT HERE]}

Figure 1 in the online Appendix 2 illustrates a similar case for a number of countries. Whenever a financial crisis occurs in a situation where the poverty levels are stable (like in Argentina for example), the poverty measure jumps up and when a financial crisis strikes where poverty is on a downward trend (like in the case of Brazil or Mexico), the measure of poverty increases.

\section{Econometric modelling, results and robustness checks}

Given that a solid and sound theoretical model in the area of financial crises and poverty is lacking, following Cecchetti et al (2009), we argue that the best way to empirically capture the impact of financial crises on poverty involves culling from the literature the most commonly used control variables in other poverty related empirical studies and including variables to control for the transmission channels outlined above (change in relative price, government spending and levels of GDP per capita). In addition, we control for openness and institutional quality.

In order to gauge the impact of financial crises on poverty, we estimate the following empirical model ${ }^{6}$ : 
POVERTY MEASURE $i, t=\alpha+\beta$ CRISIS VARIABLE $i, t+\gamma$ CRISIS VARIABLE $i, t-1+$ $\delta$ CRISIS VARIABLE $i, t-2+\zeta \mathrm{X} i, t+$ error term

POVERTY MEASURE is the dependent variable, while CRISIS VARIABLE, and a vector of control variables $\mathrm{X}$, are the independent variables. The vector of control variables encompasses: economic development (captured by the log of GDP per capita) ${ }^{7}$, the level of institutional development (using Polity IV), the level of trade openness (using the ratio of total trade to GDP), as well as inflation and government spending ${ }^{8}$. The dataset consists of yearly data for 90 countries spanning the period between 1970 and $2007^{910}$.

We estimate the model using fixed effects for a number of reasons. First and foremost, due to data availability (and gaps in the poverty data in particular) estimating the effect of crises on cross country changes in poverty becomes a difficult task. Hence, estimating the impact of financial crises on levels of poverty, while controlling for other changes, seems a better approach. In addition, we assume a correlation between some of the independent variables and the time-invariant portion of the error term, which would render the OLS estimates inconsistent. Thus, fixed effects on panel data allow us to remove the abovementioned form of endogeneity while providing consistent estimates for other mildly endogenous time-varying variables. Unfortunately, fixed effects do not permit us to control for important time invariant effects (such as for example initial conditions) which is one of the caveats that we attach to our findings. Also, most of the studies dealing with panel data take into account a possible reverse causality or endogeneity. However, we assume that poverty does not have a significant impact on the possibility of a financial crisis occurring - indeed, as evidenced from our empirical examples above, financial crises happen in different types of countries in terms of poverty. This latter point is emphasized in some of the latest empirical research (Cecchetti et al., 2009). In that respect, our choice of estimation method becomes clear.

Summary statistics for the data are provided in Table 2.

[TABLE 2 ABOUT HERE]

\section{Correlations}

Correlations between data are presented in Online Appendix 2 Tables A1 and A2. Banking and debt crises are negatively correlated with some of the poverty variables. Currency crises are consistently positively correlated with all of the poverty variables.

Results and discussion 
Table 3 below presents our results when using the poverty headcount ratio at 1.25 USD a day as the dependent variable. When estimating the effect of different financial crises on poverty we proceed in the following way: the first three models use only one type of financial crisis at a time; models 4,5 and 6 use pairs of two crises, while model 7 includes all three types of financial crises. In order to capture lagged effects of the crises on poverty we employ first and second lags ${ }^{11}$.

\section{[TABLE 3 ABOUT HERE]}

We first observe that only the currency crises and only the contemporaneous values appear positive and significant (albeit at 10 percent level of significance); an occurrence of currency crisis is associated with an increase in the poverty headcount ratio by 4 percent. We would have also expected some impact of the banking crises on the poverty headcount ratio (i.e. we would have expected to see some percentage of the people that teeter around the poverty line to be sliding towards poverty as a banking crisis occurs). This however depends on many factors, such as for example, the availability of banking accounts for the citizens of the lower classes and how well they are protected (and inversely how badly they are hit) during a period of crisis, the extent to which these people use banking services etc. It could also be speculated that many of the vulnerable people may be sheltered by some of the microcredit institutions. However, given the scope of our study as well as the data we use, some of these questions cannot be answered.

Table 4 gives the results of our specifications when using the poverty gap at 1.25 USD a day as a measure of poverty. The estimation strategy here is the same as in Table 3 . There are two main conclusions. First, when analyzing the cumulative effect of the banking crises on the incidence of poverty, the overall effect is positive, though it diminishes over time. Second, the impact of banking crises upon poverty incidence is ephemeral, i.e. while banking crisis is associated with increases in poverty depth contemporaneously, its first lag is associated with decreases in poverty (though the level of significance is somewhat low - 10 percent). Given that most poor people are on the fringes of the banking systems in most developing countries (and hence take up only a small percentage of the financial sector), this result does not come as a surprise.

\section{[TABLE 4 ABOUT HERE]}

The currency crisis dummy is also positive and significant, and with a magnitude which is much higher than the magnitude of the banking crisis variable. Currency crises however appear positive and significant only contemporaneously (though as in the case above, the level of significance is somewhat lower). As indicated in our transmission channels section, currency crises are almost always associated with a downturn of economic activity as well as relative price changes, which invariably hurt the poor, hence pushing them further below the poverty line.

The debt crises dummy appears insignificant across all specifications; sovereign debt default crises may not affect the welfare of the existing poor as much as banking or 
currency crises. Even though they may trigger additional banking or currency crises, they in themselves are not associated with significant changes in the levels of poverty. Our result is similar to Cecchetti et al (2009) who find that debt crises do not matter for the slowdown of economic activity as much as banking and currency crises. Finally, one has to be careful when interpreting the effect of the debt crises as the result could be driven by the low number of debt crisis episodes in our sample.

The control variables appear to comply with the existing knowledge in the area of poverty research. Trade openness is associated with lower levels of poverty, as previously confirmed by many studies such as Dollar and Kraay (2001). The findings regarding democracy confirm Ross (2006). Unsurprisingly, higher levels of development are associated with a lower depth of poverty ${ }^{12}$. The variables that capture the two additional transmission channels (inflation and government spending) appear insignificant.

The results that we have obtained when using relative measures of poverty as dependent variables (poverty headcount ratio at 2 USD a day and poverty gap at 2 USD a day) are quite similar (in terms of significance and magnitude) to the results obtained when using the measures of absolute poverty (see Appendix 2, Tables A3 and A4). As in the case of using the poverty headcount ratio at 1.25 USD a day, here as well, only the currency crisis dummy is positive and significant. In addition, the variable is significant in its first lag as well, suggesting that the effect of the currency crisis is not only immediate but could also be felt for some time after the beginning of the crisis. We would have expected the banking crises to have a more pronounced impact on the levels of poverty, however, again most of the poor (even in relative terms) are on the fringes of the financial systems in most developing countries and hence, a banking crisis could not impact much upon their situation.

As in the case when using the poverty gap at 1.25 USD a day, when the 2 USD a day measure is used, banking crisis is contemporaneously positive and significant (albeit at 10 percent level of significance). The magnitude of the banking crises however is smaller (and it also decreases with time), which confirms our previous finding - i.e. that banking crises matter less for poverty than currency crises and that their impact over time decreases. The results regarding the currency crises are somewhat different. Here, we can observe that the effect of currency crises is bigger than that of banking crises and lasts longer.

To summarise, there are five key findings that stem from this first attempt to measure the cross-country impact of disaggregated financial crises on poverty:

(i) currency crises are associated with higher levels of poverty as well as higher depth of poverty (which for some measures of poverty could also be felt for some time after the beginning of the crisis).

(ii) Banking crises are associated with higher depth of poverty but they do not seem to matter for the incidence of poverty;

(iii) Banking crises, to the extent that they are significant at all, tend to be rather ephemeral in nature (i.e. their effect diminishes over time). 
(iv) Debt crises are not associated with any changes in poverty.

(v) Results i-iv are robust to the inclusion of standard control variables (level of development, trade openness, institutional development, inflation and government spending) which in turn produce estimates consistent with the literature.

Our results come with a caveat however. When they appear to matter for poverty, the crises variables are significant at relatively low levels ( 5 or 10 percent). Hence, the results should be interpreted with caution - they are far from conclusive and give only partial indication of the poverty-crises nexus.

\section{Robustness checks}

In order to confirm our finding that different types of financial crises have an independent impact upon poverty, we created two new variables, called double and triple crises (which capture the simultaneous occurrence of a double and a triple crisis respectively reported in Tables 5 and 6). While the results when using the double crisis variable are positive and significant across all specifications (albeit only contemporaneously), the results when using the triple crisis are rather weak in terms of significance and inconsistent in terms of sign. Moreover, their impact tends to decrease over time. These results should not come as a surprise. The number of triple crisis episodes in our sample is relatively small and in addition, crisis transmission mechanisms could often act in opposing way, thus driving the magnitude and significance of the final results. Furthermore, these results could represent additional evidence for the independent impact of the different types of financial crises.

\section{[TABLE 5 and TABLE 6 ABOUT HERE]}

Our second robustness check consists in running a difference-in-difference estimation. The results are reported in tables 7, 8 and 9. In order to conduct the difference in difference methodology we proceeded the following way. We first created a variable currency, banking or debt crisis which takes value of 1 when the variable is in the post period and 0 otherwise. We then created variable treatment group (countries where the particular crisis has not occurred) which takes value 1 if the observation is in the treatment group and 0 otherwise. Finally, we created an interaction variable which is the difference in difference estimator between the two variables. The results that we obtain are consistent with our findings from above, i.e. that of the three types of crises, it is the currency crises which matter the most for poverty, while banking and debt crises tend to be mute in most cases ${ }^{13}$.

\section{[TABLE 7, TABLE 8 and TABLE 9 ABOUT HERE]}

In order to see whether our findings would differ if conducted on separate sub-samples (based on level of income or geographical area) we conducted the same analysis as above but on separate sub-groups of countries (divided on low, lower middle and upper middle income countries and on Europe Central Asia, Latin America, Middle East North Africa, 
East Asia and the Pacific, South Asia and Africa), while also testing for the equality of coefficients across different income and geographical groups. The results confirmed that the impact of different financial crises is consistent across countries, supporting our use of pooled data (results available on request).

While we are primarily interested in the link financial crises occurrence and poverty, a final robustness check was undertaken in order to explore whether the severity of different types of crises may have a differential impact on the levels of poverty. An index of severity of crises was constructed for all three types of crises, ranging from 1 (low severity) to 3 (extremely severe crises) ${ }^{14}$. The results support the findings above (see Appendix 3, Tables A1, A2, A3 and A4), i.e. of the three types of financial crises, it is the currency crises that are associated with the most profound impact on poverty, while the banking crises are only contemporaneously associated with increases in poverty levels. In addition to these main results, we also find limited evidence that debt crises are associated with increases in poverty levels (although only contemporaneously).

\section{Conclusion and directions for further research}

The current financial crisis, which has slowly evolved into a global economic crisis, has rekindled interest among social scientists for re-examining the link between financial crises and poverty. This paper empirically analyzed this relationship using a panel dataset for 90 developing countries over the period 1970-2007. By using data on financial crises (disaggregated into banking, currency and debt) and employing fixed effects in order to deal with the unobserved heterogeneity, we obtain several new findings. We confirm the established notion that crises are bad for the poor but, more subtly, that the type of crisis matters. In particular, currency crises are associated with higher levels of both the poverty headcount ratio and the poverty gap (measured both at 1.25 USD and 2 USD a day). Banking crises are associated with higher values only for the depth of poverty (rather than the incidence of poverty) and any significance dissipates quickly. Finally, there is no evidence for a direct relationship between debt crises and poverty. The results are confirmed when severity of financial crises is taken into consideration.

There are however caveats. While there is internationally comparable data on poverty, poverty is an individual experience, and aggregate measures may not adequately capture the distribution of effects of crises. Nevertheless, by purging the country-specific effects, some generalizations are suggested that, coupled with individual case studies, could shed further light onto the issue of financial crises and poverty. It may also reflect the quality of the data that when the crises variables are significant they are only so at relatively low levels ( 5 or 10 percent). Hence, the results should be interpreted with caution - they are far from conclusive and offer only partial indications.

Future research, data permitting, could introduce an auto-regressive term to explore the medium- and long-term impact of financial crises on poverty. Indeed, crises come and go and poverty levels increase and decrease over time. However, a necessary policy solution should be found in case recurrent financial crises over longer periods of time significantly impede the process of poverty alleviation. 
Bibliography

Agenor, P. (2002) Business cycles, economic crises and the poor. Journal of Economic Policy Reform, 5(3), pp. 145-160.

Atinc, T. and Michel W. (1999) Social Consequences of the East Asian Financial Crisis World Bank, Washington DC, Processed.

Baldacci, E., de Mello L. and Inchauste G. (2002) Financial Crises, Poverty and Income distribution. IMF Working Paper WP/02/4 (Washington DC: International Monetary Fund).

Beim, D. and Calomiris C. (2001) Emerging Financial Markets. Appendix to Chapter 1. New York: McGraw-Hill/Irwin Publishers.

Berg, A. and Kureger A. (2002) Trade, growth and poverty. 2002 Annual Bank Conference on Development Economics.

Bourguignon, F. and Morrisson C. (1992) Adjustment and Equity in Developing Countries: a new approach. (Paris: Organization of Economic Cooperation and Development).

Cardoso, E. (1992) Inflation and poverty. NBER working paper \#4006, March 1992.

Cashin, P., Sahay R., Patillo C., and Mauro P. (2001) Macroeconomic policies and poverty reduction: stylized facts and overview of research. IMF working paper WP/01/135 (Washington: International Monetary Fund).

Cecchetti S., Kohler M. and Upper C. (2009) Financial Crises and Economic activity. NBER working paper No.15379.

Chen, S and Wang Y. (2002) China's growth and poverty reduction in the recent years in Khandker, S.(eds) The impact of the Asian financial crisis revisited (Washington DC, World Bank, 2002), pp. 193-221.

Cline, W. (2002) Financial crises and Poverty in Emerging Market economies. Center for Global Development, Working Paper Number 8, June 2002.

Dollar D. (2001) Globalization, Inequality and Poverty since 1980. Background paper, World Bank, Washington DC, 2001.

Dollar, D. and Kraay A. (2002) Growth is good for the poor. Journal of Economic Growth, 7(3), pp. 195-225.

Easterly, W. (2001) The Elusive Quest for Growth: The Economists' Adventures and Misadventures in the Tropics (Cambridge, Mass: MIT Press).

Easterly, W. and Fischer S. (2000) Inflation and the poor. World Bank Policy Research Working paper 2335 World Bank, Washington DC.

Fallon, P. and Lucas R. (2002) The Impact of financial crises on labor markets, household incomes, and poverty: a review of evidence, The World Bank Research Observer, 17(1), pp. 21-45.

Ferreira, F. and Ravallion M. (2009) Global poverty and inequality: a review of the evidence, Oxford Handbook of Economic Inequality, Oxford University Press 2009.

Flood, R. and Marion N. (1997) Policy Implications of ‘second-generation' crisis models. IMF Staff Papers, 44(3) pp.383-90.

Frankel, J. and Rose A., (1996) Currency Crashes in Emerging Markets: An Empirical Treatment. Journal of International Economics, 41 (3-4), pp. 351-66. 
Gerry, C. and Li C. (2010) Consumption smoothing and Vulnerability in Russia forthcoming in the Applied Economics.

Guillaumont Jeanneney, S. and Kpodar, K. (2011) Financial Development and Poverty Reduction: Can There Be a Benefit Without a Cost?, Journal of Development Studies, forthcoming

Laeven, L. and Valencia F. (2008) Systemic Banking Crises: a New database. IMF Working Paper, WP/08/224 (Washington DC: International Monetary Fund)

Lokshin M. and Ravallion, M. (2000) Welfare impacts of the 1998 financial crisis in Russia and the response of the public safety net. Economics of Transition 8(2), pp.269-295.

Lokshin, M. and Yemtsov, R. (2004) Household Strategies for coping with shocks in post-crisis Russia. Review of Development Economics, 8(1), pp.15-32.

Lustig, Nora (2000) Crises and the poor: Socially Responsible Macroeconomics, InterAmerican Development Bank, Washington DC (manuscript).

Lustig, N. and Walton M., (1998) Crises and the Poor: a Template for Action (unpublished, Washington, The World Bank and the Inter-American development bank).

Morduch, J. (2002) Consumption smoothing across space: testing theories of risk-sharing in the ICRISAT Study region of South India. Discussion paper No. 2002/55.

Morley, S., (1995) Poverty and inequality in Latin America: the Impact of Adjustment and Recovery in the 1980s. (Baltimore: The Johns Hopkins University Press).

Natenuj, S. (2002) Poverty and inequality during the crisis period in Thailand, in Khandker, S. (eds) The impact of the East Asian crisis revisited (The World Bank, Washington DC, 2002), pp. 63-99.

Park, N. (2002) The Poverty rate in Korea and the impact of the financial crisis in Khandker, S. (eds) The Impact of the Asian financial crisis revisited (World Bank, Washington DC, 2009), pp. 101-116.

Rai, A., Topa G. and Amin S. (1999) Does Microcredit Reach the Poor and Vulnerable? Evidence from Northern Bangladesh. Center for International Development, Harvard University, Cambridge, Massachusetts, Processed.

Ravallion, M. (2009) Why don't we see poverty convergence? The World Bank Poverty Research Working Paper 4974.

Ravallion, M. (2001) Growth, inequality and poverty: looking beyond averages. World Development, 29(11), pp.1803-1815.

Ravallion M. and Bidani B. (1993) How robust is poverty profile. World Bank Policy Research Working Paper 1223.

Ross, M. (2006) Is democracy good for the poor? American Journal of Political Science 50(4), pp. 860-874.

Said, A. and Widyanti W. (2002) The impact of the financial crisis on poverty and inequality in Indonesia in Khandkar, S. (eds) The impact of the Asian financial crisis revisited (The World Bank, Washington DC, 2002) pp. 117-189.

Skoufias, E. (2003) Consumption smoothing in Russia: Evidence from the RLMS. The Economics of Transition, 11(1), pp. 67-91.

Sturzenegger, F., and Zettelmeyer J. (2006) Debt Defaults and Lessons from a Decade of Crises Table 1 in Chapter 1, Cambridge: MIT Press. 
Suryahadi, A. and Sumarto S. (2003) Poverty and Vulnerability in Indonesia before and after the economic crisis. Asian Economic Journal, 17(1), pp. 45-64.

Walton, M. and Manuelyan T. (1998) Social consequences of the East Asian Financial crisis. in East Asia: the Road to Recovery (Washington, the World Bank).

Winters, A. (2000) Trade, Trade Policy and Poverty: What are the Links? CEPR London and Center for Economic Performance, London School of Economics.

Winters, A., McCulloch N. and McKay A. (2004) Trade Liberalization and Poverty: the Evidence so far. Journal of Economic Literature, Vol. 42 (March 2004), pp. 72-115.

The World Bank (2009), Europe and Central Asia Department, "Crisis hits home" (2009).

The World Bank (2003), Argentina Crisis and Poverty 2003, A Poverty Assessment, July 24, 2003, Report No. 26127-AR.

The World Bank (2000), Ecuador, Crisis, Poverty and Social Services, Poverty Assessment, June 26, 2000, Report No. 19920-EC.

Zin, R. (2002) The Impact of the Financial Crisis on poverty and inequality in Malaysia in Khandker, S. (eds) The Impact of the East Asian Crisis Revisited (The World Bank, Washington DC, 2002) pp.15-61.

\footnotetext{
${ }^{1}$ Although Checcetti et al (2009) do make distinction between the three different types of financial crises, they give the biggest weight to the banking crises and treat the other two only as an auxiliary to the banking crises.

${ }^{2}$ In relative terms however, this will depend on the level of the initial inequality as well as whether there are growth induced distributional changes.

${ }^{3}$ If we were to believe that the impact of financial crises on levels of poverty goes only through economic activity, then it would have sufficed to analyze the impact of financial crises on economic activity only and infer from that the indirect effect of financial crises on poverty.

${ }^{4}$ It is important to note that a debt crisis occurring on its own (not coupled with a currency crisis - Latin American style) is fundamentally different than a combination of a debt and a currency crisis. In the dataset used more than half of the debt crisis episodes belong to the former category. In any case, we explore both hypotheses (independent debt crisis and a twin crisis in our empirical section).

${ }^{5}$ Further description of the poverty data (including a note on the shortfalls of using aggregate poverty data) is in Appendix 1.

${ }^{6}$ In building the model, we employ a gradual approach, i.e. we start with a Ravallion-like simple relationship between poverty and GDP per capita and slowly introduce the other variables.

${ }^{7}$ In order to control for the additional channel of crisis transmission (slowdown in economic activity) we also experiment with using changes in per capita GDP (PPP), while also controlling for GDP per capita levels. We however find that the changes in GDP per capita are insignificant.

${ }^{8}$ A more detailed description of the control variables (including the sources of data and data availability) is presented in Appendix 2. We considered including levels of unemployment and remittances as independent variables (which though decimate the dataset due to data unavailability). We have also controlled for the level of financial sector development (credit to the private sector in percent of GDP), however, the variable appears insignificant.

${ }^{9}$ We also experimented with controlling for the level of inequality (in order to examine whether countries with lower levels of inequality tend to weather the financial crisis better, vis-à-vis their poverty indicators) however the results were not robust.

${ }^{10} \mathrm{We}$ considered including the informal sector but encountered problems: (i) data on informal sector economy is available only from mid 1990s onwards; (ii) the within-country variability is low, which would have produced insignificant results; (iii) in light of our labour market transmission channel it is not convincing to argue the impact of the financial crisis would have been lower in countries with sizeable informal sector. We also considered controlling for the mitigation impact of social safety nets.

Unfortunately, the social safety nets in terms of design and target vary from a country to a country, which
} 
renders it difficult to use them in a cross-country regression. A cross-country dataset on types, effectiveness and ultimately, coverage, of social safety nets is still lacking.

${ }^{11}$ We also explore the impact of including third, fourth and fifth lag of the crisis variables, however, these appear insignificant across all of our specifications.

${ }^{12}$ We also introduce an interactive term between GDP per capita (PPP) and the crises variables. The variable however appears insignificant (the same could be concluded by post-estimation testing of a linear combination between the two variables).

${ }^{13}$ In addition, we conducted a robustness check which consisted in running system GMM (while also including lagged dependent variable as a regressor). The obtained results however were weak, mainly driven by the unavailability of poverty data. In addition the specification did not pass the Hansen test so GMM appeared inappropriate for the data.

${ }^{13}$ The following indicators were used when constructing the index. For currency crises the cumulative level of depreciation was taken in consideration and the crises were divided into three groups, depending on their level of severity. For the index of the severity of banking crises, output loss associated with banking crises (as per Laeven and Valencia, 2008) was used. In addition, additional robustness check was provided by constructing a composite index that included the fiscal cost and the percentage of NPLs. Finally, for debt crises, output loss (given the lack of any additional measure), was used in order to construct the index.

14 The following indicators were used when constructing the index. For currency crises the cumulative level of depreciation was taken in consideration and the crises were divided into three groups, depending on their level of severity. For the index of the severity of banking crises, output loss associated with banking crises (as per Laeven and Valencia, 2008) was used. In addition, additional robustness check was provided by constructing a composite index that included the fiscal cost and the percentage of NPLs. Finally, for debt crises, output loss (given the lack of any additional measure), was used in order to construct the index. 


\section{Page 17 of 30}

Journal of Development Studies

Table 1. Aggregate measures of poverty before, at onset and after a specific financial crisis

\begin{tabular}{|c|c|c|c|c|c|}
\hline & Number of crises & $\begin{array}{l}\text { Poverty headcount } \\
\text { ratio at } 1.25 \text { USD a } \\
\text { day, } \mathrm{t}-1\end{array}$ & $\begin{array}{l}\text { Poverty headcount } \\
\text { ratio at } 1.25 \text { USD a } \\
\text { day, } t+1\end{array}$ & $\begin{array}{l}\text { Poverty gap at } \\
1.25 \text { USD a day, } \\
\mathrm{t}-1\end{array}$ & $\begin{array}{l}\text { Poverty gap at } \\
1.25 \text { USD a day, } \\
t+1\end{array}$ \\
\hline Banking Crisis & 44 & 22.71 & 20.93 & 10.33 & 7.81 \\
\hline Currency Crisis & 40 & 15.40 & 17.86 & 6.18 & 6.69 \\
\hline \multirow[t]{2}{*}{ Debt Crisis } & 13 & 7.81 & 7.62 & 2.27 & 2.80 \\
\hline & & $\begin{array}{l}\text { Poverty headcount } \\
\text { ratio at } 2 \text { USD a day, } t \\
1\end{array}$ & $\begin{array}{l}\text { Poverty headcount } \\
\text { ratio at } 2 \text { USD a } \\
\text { dav. } t+1\end{array}$ & $\begin{array}{l}\text { Poverty gap at } 2 \\
\text { USD a day, } \mathrm{t}-1\end{array}$ & $\begin{array}{l}\text { Poverty gap at } 2 \\
\text { USD a day, } t+1\end{array}$ \\
\hline Banking Crisis & 44 & 34.68 & 35.52 & 17.04 & 15.50 \\
\hline Currency Crisis & 40 & 27.04 & 31.36 & 11.71 & 13.36 \\
\hline Debt Crisis & 13 & 17.10 & 19.37 & 5.95 & 6.22 \\
\hline
\end{tabular}

Source: World Development Indicators and Laeven and Valencia (2008)

Table 2. Summary of Observations

\begin{tabular}{lccccc}
\hline \multicolumn{1}{c}{ Variable } & Number of Observations & Mean & Standard Deviation & Minimum & Maximum \\
\hline Poverty headcount ratio at 1.25 USD a day & 417 & 20.76 & 23.19 & 2.00 & 88.52 \\
Poverty gap at 1.25 USD a day & 417 & 7.99 & 11.14 & 0.50 & 56.96 \\
Poverty headcount ratio at 2 USD a day & 417 & 34.30 & 29.17 & 2.00 & 96.56 \\
Poverty gap at 2 USD a day & 417 & 15.57 & 16.69 & 0.50 & 68.36 \\
Banking crisis & 417 & 0.05 & 0.21 & 0.00 & 1.00 \\
Currency crisis & 417 & 0.04 & 0.19 & 0.00 & 1.00 \\
Debt crisis & 417 & 0.01 & 0.10 & 0.00 & 1.00 \\
Log of GDP per capita PPP & 417 & 8.22 & 0.92 & 5.78 & 10.02 \\
Openness & 417 & 73.93 & 39.10 & 13.64 & 210.37 \\
Polity2 & 417 & 2.51 & 12.29 & -88.00 & 10.00 \\
Inflation & 417 & 63.19 & 413.24 & -4.48 & 7481.68 \\
Government expenditure & 417 & 13.93 & 4.92 & 2.98 & 31.82 \\
\hline
\end{tabular}


Table 3 - Fixed effects regression results while using Poverty Headcount ratio at 1.25 USD a day

\begin{tabular}{|c|c|c|c|c|c|c|c|}
\hline & Model 1 & Model 2 & Model 3 & Model 4 & Model 5 & Model 6 & Model 7 \\
\hline Banking crisis & $2.11(1.40)$ & & & $1.93(1.44)$ & $1.85(1.43)$ & & $1.85(1.47)$ \\
\hline Banking crisis (lagged) & $-1.13(1.32)$ & & & $-1.71(1.42)$ & $-1.10(1.32)$ & & $-1.79(1.82)$ \\
\hline Banking crisis (second lag) & $-0.43(0.93)$ & & & $-0.67(1.10)$ & $-0.33(0.93)$ & & $-0.74(1.09)$ \\
\hline Currency crisis & & $4.44 *(2.29)$ & & $4.56^{* *}(2.31)$ & & $4.22^{*}(2.40)$ & $4.39 *(2.45)$ \\
\hline Currency crisis (lagged) & & $2.07(1.49)$ & & $2.29(1.50)$ & & $1.98(1.50)$ & $2.19(1.53)$ \\
\hline Currency crisis (second lag) & & $-0.66(1.28)$ & & $-0.050(1.32)$ & & $-0.74(1.32)$ & $-0.64(1.35)$ \\
\hline Debt crisis & & & $4.56(3.46)$ & & $4.08(3.61)$ & $2.58(3.18)$ & $2.02(3.64)$ \\
\hline Debt crisis (lagged) & & & $0.67(2.10)$ & & $1.32(2.16)$ & $-0.025(2.46)$ & $0.77(2.46)$ \\
\hline Debt crisis (second lag) & & & $0.53(2.17)$ & & $0.73(2.26)$ & $1.15(2.23)$ & $1.39(2.33)$ \\
\hline Openness & $-0.039 *(0.022)$ & $-0.045 * *(0.022)$ & $-0.043 *(0.022)$ & $-0.045 * *(0.022)$ & $-0.042 *(0.022)$ & $-0.047 * *(0.022)$ & $-0.046 * *(0.022$ \\
\hline Polity IV & $-0.031(0.023)$ & $-0.030(0.021)$ & $-0.023(0.025)$ & $-0.032(0.023)$ & $-0.030(0.023)$ & $-0.029(0.023)$ & $-0.032(0.023)$ \\
\hline Log of GDP per capita & $-15.77 * * *(2.43)$ & $-14.58 * * *(2.57)$ & $-15.30 * * *(2.45)$ & $-14.57 * * *(2.57)$ & $-15.64 * * *(2.43)$ & $-14.55 * * *(2.57)$ & $-14.89 * * *(2.58)$ \\
\hline Government expenditure & $-0.068(0.15)$ & $-0.045(0.14)$ & $-0.063(0.15)$ & $-0.038(0.15)$ & $-0.068(0.15)$ & $-0.047(0.14)$ & $-0.039(0.14)$ \\
\hline Inflation & $0.032(1.02)$ & $-0.45(0.94)$ & $0.048(0.96)$ & $-0.048(1.00)$ & $0.018(1.02)$ & $-0.44(0.94)$ & $-0.49(1.14)$ \\
\hline Number of observations & 417 & 417 & 417 & 417 & 417 & 417 & 417 \\
\hline Number of groups & 90 & 90 & 90 & 90 & 90 & 90 & 90 \\
\hline
\end{tabular}

Note: Standard errors are reported in parentheses. ${ }^{*}$ indicates significance at 10 percent, ${ }^{* *}$ indicates significance at 5 percent, ${ }^{\star \star *}$ indicates significance at 1 percent level of significance respectively 
Table 4 - Fixed effects regression results while using Poverty Gap at 1.25 USD a day as a dependent variable

\begin{tabular}{|c|c|c|c|c|c|c|c|}
\hline & Model 1 & Model 2 & Model 3 & Model 4 & Model 5 & Model 6 & Model 7 \\
\hline Banking crisis & $2.21^{*}(1.17)$ & & & $2.12 *(1.17)$ & $2.13 *(1.19)$ & & $2.14 *(1.17)$ \\
\hline Banking crisis (lagged) & $-0.947(0.66)$ & & & $-1.30 *(0.75)$ & $-1.11(0.71)$ & & $-1.41 *(0.81)$ \\
\hline Banking crisis (second lag) & $-0.352(0.45)$ & & & $-0.59(0.54)$ & $-0.33(0.47)$ & & $-0.61(0.54)$ \\
\hline Currency crisis & & $2.79^{*}(1.47)$ & & $2.88 *(1.49)$ & & $2.74 *(1.55)$ & $2.86 *(1.56)$ \\
\hline Currency crisis (lagged) & & $1.32(1.041)$ & & $1.49(1.049)$ & & $1.29(1.06)$ & $1.47(1.07)$ \\
\hline Currency crisis (second lag) & & $-0.0166(0.789)$ & & $0.15(0.82)$ & & $-0.017(0.83)$ & $0.09(0.85)$ \\
\hline Debt crisis & & & $1.83(1.63)$ & & $1.31(1.83)$ & $0.61(1.50)$ & $-0.001(1.74)$ \\
\hline Debt crisis (lagged) & & & $0.55(0.886)$ & & $1.13(0.91)$ & $0.037(1.19)$ & $0.69(1.14)$ \\
\hline Debt crisis (second lag) & & & $-0.149(0.830)$ & & $0.056(0.86)$ & $0.085(0.89)$ & $0.32(0.93)$ \\
\hline Openness & $-0.0279(0.0139)$ & $-0.0321^{* *}(0.014)$ & $-0.030^{* *}(0.014)$ & $-0.031 * *(0.014)$ & $-0.030 *(0.014)$ & $-0.032 * *(0.015)$ & $-0.032 * *(0.014)$ \\
\hline Polity IV & $-0.018(.0015)$ & $-0.015(0.015)$ & $-0.014(0.015)$ & $-0.018(0.016)$ & $-0.016(0.015)$ & $-0.015(0.016)$ & $-0.017(0.015)$ \\
\hline Log of GDP per capita & $-5.297^{\star \star \star}(1.460)$ & $-4.397^{* * *}(1.555)$ & $-4.896 * * *(1.516)$ & $-4.65 * * *(1.55)$ & $-5.17 * * *(1.48)$ & $-4.39 * * *(1.62)$ & $-4.64 * * *(1.57)$ \\
\hline Government expenditure & $0.0860(0.112)$ & $0.099(0.106)$ & $0.0875(0.109)$ & $0.10(0.11)$ & $0.087(0.114)$ & $0.09(0.10)$ & $0.10(0.11)$ \\
\hline Inflation & $0.703(0.289)$ & $0.426(0.586)$ & $0.776(0.649)$ & $0.36(0.69)$ & $0.71(0.67)$ & $0.42(0.59)$ & $0.36(0.61)$ \\
\hline Number of observations & 417 & 417 & 417 & 417 & 417 & 417 & 417 \\
\hline Number of groups & 90 & 90 & 90 & 90 & 90 & 90 & 90 \\
\hline
\end{tabular}

Note: Standard errors are reported in parentheses. ${ }^{*}$ indicates significance at 10 percent, ${ }^{* *}$ indicates significance at 5 percent, ${ }^{* * *}$ indicates significance at 1 percent level of significance respectively 
Table 5 - Fixed effects regression results while using double crisis as an independent variable

\begin{tabular}{|c|c|c|c|c|}
\hline & Model 1 - Absolute poverty gap & Model 2 - Absolute Poverty ratio & Model 3 - Relative Poverty Gap & Model 4 - Relative Poverty Ratio \\
\hline Double crisis & $5.89^{\star \star \star}(.507)$ & $12.707^{\star \star \star}(.739)$ & $9.539^{\star \star \star}(.552)$ & $18.443^{\star \star \star}(.750)$ \\
\hline Double crisis (lagged) & $-1.178(1.169)$ & $-1.891(3.056)$ & $-1.419(2.333)$ & $-1.714(4.747)$ \\
\hline Double crisis (second lag) & $.772(1.160)$ & $3.095(2.344)$ & $1.624(2.144)$ & $2.779(6.180)$ \\
\hline Openness & $-0.029^{\star \star}(0.014)$ & $-0.042^{\star}(0.022)$ & $-0.035^{\star \star}(0.016)$ & $-0.042^{*}(0.024)$ \\
\hline Polity IV & $-0.014(.0015)$ & $-0.026(.0023)$ & $-0.017(.0016)$ & $-0.015(.0021)$ \\
\hline Log of GDP per capita & $-4.91^{* \star \star}(1.505)$ & $-15.199^{\star \star \star}(2.460)$ & $-10.313^{\star \star \star}(1.737)$ & $-21.330^{\star \star \star}(2.525)$ \\
\hline Government expenditure & $0.083(0.108)$ & $-0.068(0.150)$ & $-0.015(0.117)$ & $-0.286^{*}(0.162)$ \\
\hline Inflation & $0.792(0.652)$ & $0.079(0.973)$ & $0.381(0.711)$ & $-0.580(0.928)$ \\
\hline Constant & $49.125^{\star \star \star}(12.168)$ & $149.899^{* \star *}(20.182)$ & $102.855^{\star \star \star}(14.193)$ & $49.125^{\star \star \star}(12.168)$ \\
\hline Number of observations & 417 & 417 & 417 & 417 \\
\hline Number of groups & 90 & 90 & 90 & 90 \\
\hline
\end{tabular}

Note: Standard errors are reported in parentheses. ${ }^{*}$ indicates significance at 10 percent, ${ }^{* *}$ indicates significance at 5 percent, ${ }^{* \star *}$ indicates significance at 1 percent level of significance respectively

Table 6 - Fixed effects regression results while using tripple crisis as an independent variable

\begin{tabular}{|c|c|c|c|c|}
\hline & Model 1 - Absolute poverty gap & Model 2 - Absolute Poverty ratio & Model 3 - Relative Poverty Gap & Model 4 - Relative Poverty Ratio \\
\hline Tripple crisis & $.667(1.012)$ & $3.554(2.195)$ & $2.226(1.484)$ & $5.218^{*}(3.043)$ \\
\hline Tripple crisis (lagged) & $-1.177^{\star}(.615)$ & $-3.472^{* * *}(1.282)$ & $-.952(.717)$ & $2.032(1.575)$ \\
\hline Triple crisis (second lag) & $.562(.754)$ & $3.44^{\star \star}(1.551)$ & $2.143^{\star \star}(1.076)$ & $5.495^{\star}(2.165)$ \\
\hline Openness & $-0.028^{\star *}(0.014)$ & $-0.037^{\star}(0.022)$ & $-0.032^{* *}(0.016)$ & $-0.037(0.025)$ \\
\hline Polity IV & $-0.015(.0015)$ & $-0.027(.0023)$ & $-0.017(.0016)$ & $-0.015(.0021)$ \\
\hline Log of GDP per capita & $-5.099^{\star * *}(1.539)$ & $-15.867^{\star \star \star}(2.487)$ & $-10.690^{\star \star \star}(1.771)$ & $-22.012^{\star \star \star}(2.567)$ \\
\hline Government expenditure & $0.083(0.108)$ & $-0.075(0.151)$ & $-0.016(0.118)$ & $-0.283^{*}(0.163)$ \\
\hline Inflation & $0.761(0.660)$ & $-0.020(0.984)$ & $0.316(0.719)$ & $-0.707(0.942)$ \\
\hline Constant & $50.581^{\star \star \star}(12.475)$ & $155.237^{\star \star \star}(20.411)$ & $105.824^{\star \star \star}(14.473)$ & $222.487^{\star \star \star}(21.251)$ \\
\hline Number of observations & 417 & 417 & 417 & 417 \\
\hline Number of groups & 90 & 90 & 90 & 90 \\
\hline
\end{tabular}

Note: Standard errors are reported in parentheses. ${ }^{*}$ indicates significance at 10 percent, ${ }^{* *}$ indicates significance at 5 percent, ${ }^{* * *}$ indicates significance at 1 percent level of significance respectively 
Table 7. Difference in difference estimator for banking crises

\begin{tabular}{|c|c|c|c|c|}
\hline & Model 1 - Absolute poverty gap & Model 2 - Absolute Poverty ratio & Model 3 - Relative Poverty Gap & Model 4 - Relative Poverty Ratio \\
\hline Joint variable (treatment group and post-effect) & $-1.792(1.138)$ & $-1.435(1.770)$ & $-1.121(1.328)$ & $.580(1.722)$ \\
\hline Banking crisis & $2.31^{*}(1.37)$ & $1.950(1.605)$ & $1.997(1.368)$ & $1.346(1.837)$ \\
\hline Treatment group & $-2.649(3.582)$ & $-10.164(8.491)$ & $-7.241(5.981)$ & $-17.891^{*}(9.851)$ \\
\hline Constant & $12.803^{\star \star \star}(3.582)$ & $34.623^{\star \star \star}(7.992)$ & $25.201^{\star \star \star}(5.569)$ & $55.384(9.267)$ \\
\hline Number of observations & 479 & 477 & 477 & 479 \\
\hline Number of groups & 97 & 97 & 97 & 97 \\
\hline
\end{tabular}

Note: Standard errors are reported in parentheses. ${ }^{*}$ indicates significance at 10 percent, ${ }^{* *}$ indicates significance at 5 percent, ${ }^{* * *}$ indicates significance at 1 percent level of significance respectively

Table 8. Difference in difference estimator for currency crises

\begin{tabular}{|c|c|c|c|c|}
\hline & Model 1 - Absolute poverty gap & Model 2 - Absolute Poverty ratio & Model 3 - Relative Poverty Gap & Model 4 - Relative Poverty Ratio \\
\hline Joint variable (treatment group and post-effect) & $1.996^{*}(1.029)$ & $4.332^{* \star *}(1.601)$ & $3.482^{\star \star \star}(1.202)$ & $7.067^{\star \star \star}(1.864)$ \\
\hline Currency crisis & $4.258^{\star \star \star}(1.538)$ & $7.842^{\star \star \star}(2.451)$ & $5.711^{\star \star \star}(1.814)$ & $7.981^{\star \star \star}(2.535)$ \\
\hline Treatment group & $4.817(3.229)$ & $11.216(6.996)$ & $9.028^{\star}(4.903)$ & $18.954^{\star \star}(8.325)$ \\
\hline Constant & $6.246^{* \star}(2.775)$ & $16.287^{\star \star}(6.307)$ & $11.238^{\star \star}(4.354)$ & $24.169^{\star \star}(7.550)$ \\
\hline Number of observations & 479 & 477 & 477 & 479 \\
\hline Number of groups & 97 & 97 & 97 & 97 \\
\hline
\end{tabular}

Note: Standard errors are reported in parentheses. ${ }^{*}$ indicates significance at 10 percent, ${ }^{* *}$ indicates significance at 5 percent, ${ }^{* * *}$ indicates significance at 1 percent level of significance respectively

Table 9. Difference in difference estimator for debt crises

Model 1 - Absolute poverty gap Model 2 - Absolute Poverty ratio Model 3 - Relative Poverty Gap Model 4 - Relative Poverty Ratio

\begin{tabular}{|c|c|c|c|c|}
\hline Joint variable (treatment group and post-effect) & $.693(.943)$ & $2.262(2.336)$ & $1.932(1.646)$ & $4.834(3.450)$ \\
\hline Debt crisis & $1.854(1.660)$ & $4.703(3.55)$ & $3.284(2.625)$ & $6.438(4.892)$ \\
\hline Treatment group & $-.279(2.998)$ & $-3.985(5.611)$ & $-2.493(4.168)$ & $-7.901(6.576)$ \\
\hline Constant & $10.833^{\star \star \star}(2.023)$ & $28.457^{\star \star *}(4.126)$ & $20.657(2.977)$ & $45.012(5.132)$ \\
\hline Number of observations & 479 & 477 & 477 & 479 \\
\hline Number of groups & 97 & 97 & 97 & 97 \\
\hline
\end{tabular}

Note: Standard errors are reported in parentheses. ${ }^{*}$ indicates significance at 10 percent, ${ }^{* *}$ indicates significance at 5 percent, ${ }^{* * \star}$ indicates significance at 1 percent level of significance respectively 
Figure 1. Selected financial crises and poverty levels
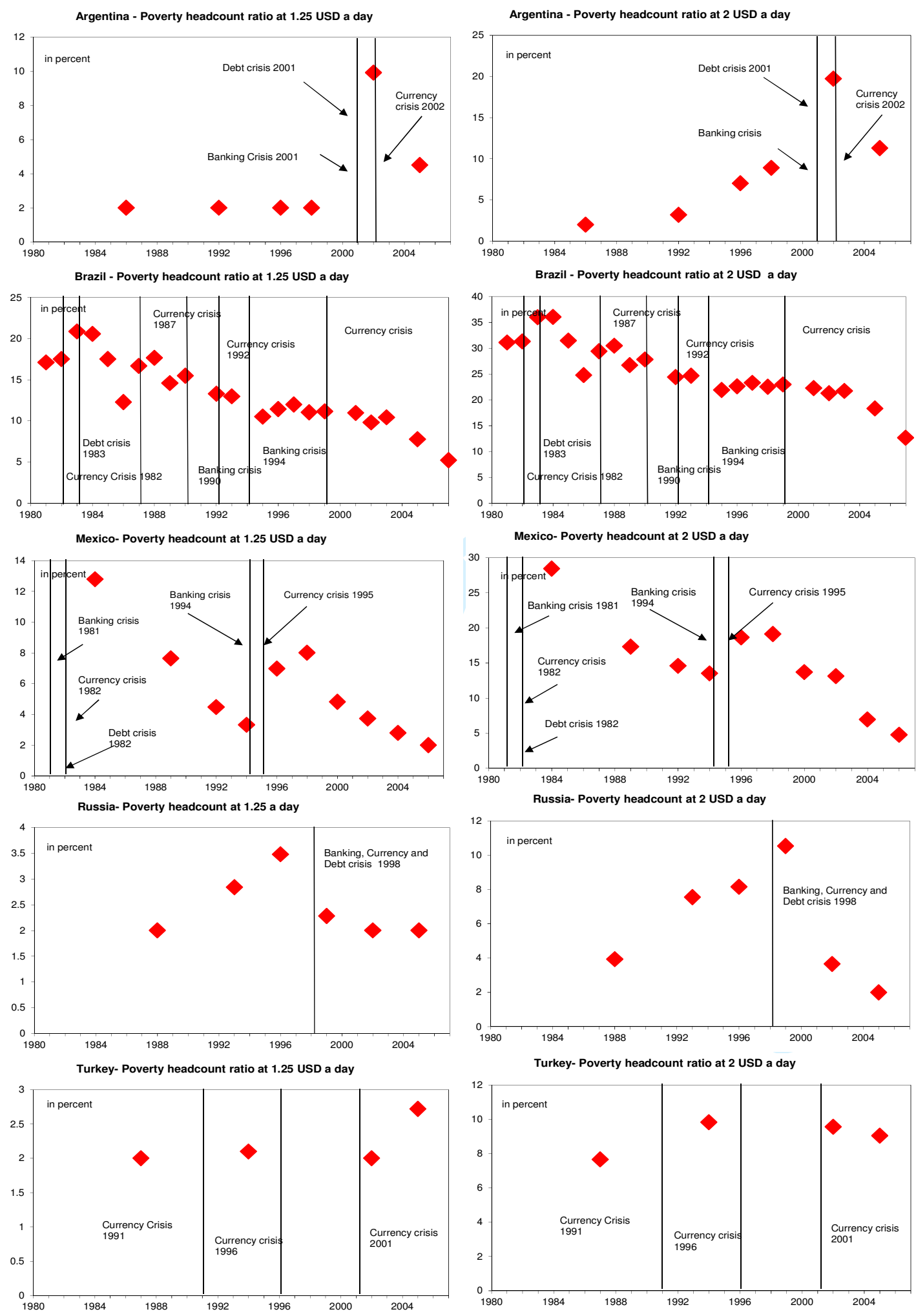

URL: http://mc.manuscriptcentral.com/fjds 
Table A1. Correlation table between the main variables used in the model (demenaed)

\begin{tabular}{|c|c|c|c|c|c|c|c|c|c|c|c|c|}
\hline & $\begin{array}{l}\text { Poverty } \\
\text { Gap at } \\
1.25 \text { USD } \\
\text { a day }\end{array}$ & $\begin{array}{l}\text { Poverty } \\
\text { ratio at } \\
1.25 \text { USD } \\
\text { a day }\end{array}$ & $\begin{array}{l}\text { Poverty } \\
\text { ratio at } 2 \\
\text { USD a } \\
\text { day }\end{array}$ & $\begin{array}{l}\text { Poverty } \\
\text { Gap at } 2 \\
\text { USD a } \\
\text { day }\end{array}$ & $\begin{array}{l}\text { Banking } \\
\text { crisis } \\
\text { dummy }\end{array}$ & $\begin{array}{l}\text { Currency } \\
\text { crisis } \\
\text { dummy }\end{array}$ & $\begin{array}{l}\text { Debt crisis } \\
\text { dummy }\end{array}$ & $\begin{array}{l}\text { GDP per } \\
\text { capita } \\
\text { (PPP) }\end{array}$ & $\begin{array}{l}\text { Trade } \\
\text { Openness }\end{array}$ & Polity & $\begin{array}{l}\text { Governme } \\
\text { nt } \\
\text { Expenditu } \\
\text { re }\end{array}$ & Inflation \\
\hline Poverty Gap at 1.25 USD a day & 1.000000 & & & & & & & & & & & \\
\hline Poverty ratio at 1.25 USD a day & 0.955800 & 1.000000 & & & & & & & & & & \\
\hline Poverty ratio at 2 USD a day & 0.863000 & 0.962100 & 1.000000 & & & & & & & & & \\
\hline Poverty Gap at 2 USD a day & 0.966900 & 0.996500 & 0.962200 & 1.000000 & & & & & & & & \\
\hline Banking crisis dummy & 0.027600 & -0.012500 & -0.023700 & -0.001100 & 1.000000 & & & & & & & \\
\hline Currency crisis dummy & 0.102500 & 0.086400 & 0.074400 & 0.091300 & 0.016000 & 1.000000 & & & & & & \\
\hline Debt crisis dummy & -0.024500 & -0.019500 & -0.008500 & -0.018000 & 0.112800 & 0.207800 & 1.000000 & & & & & \\
\hline GDP per capita (PPP) & -0.589800 & -0.680500 & -0.773600 & -0.694800 & 0.019600 & -0.062700 & -0.010900 & 1.000000 & & & & \\
\hline Trade Openness & -0.219800 & -0.271500 & -0.287300 & -0.265700 & 0.064200 & -0.087900 & 0.032800 & 0.167400 & 1.000000 & & & \\
\hline Polity & -0.145800 & -0.183300 & -0.199100 & -0.177500 & -0.014500 & 0.024700 & 0.026500 & 0.193000 & 0.090000 & 1.000000 & & \\
\hline Government Expenditure & -0.057000 & -0.127400 & -0.200800 & -0.129200 & 0.011900 & -0.001500 & -0.012800 & 0.190000 & 0.235200 & -0.041300 & 1.000000 & \\
\hline Inflation & -0.036800 & -0.056500 & -0.065600 & -0.052400 & 0.054000 & 0.173300 & 0.031600 & 0.066400 & -0.103300 & 0.030700 & 0.035000 & 1.000000 \\
\hline
\end{tabular}

Table A2. Correlation table between the main variables used in the model (demenaed) - only the values used in the estimation

\begin{tabular}{|c|c|c|c|c|c|c|c|c|c|}
\hline $\begin{array}{l}\text { Poverty } \\
\text { Gap at } \\
1.25 \text { USD } \\
\text { a day }\end{array}$ & $\begin{array}{l}\text { Poverty } \\
\text { ratio at } \\
1.25 \text { USD } \\
\text { a day }\end{array}$ & $\begin{array}{l}\text { Poverty } \\
\text { ratio at } 2 \\
\text { USD a } \\
\text { day }\end{array}$ & $\begin{array}{l}\text { Poverty } \\
\text { Gap at } 2 \\
\text { USD a } \\
\text { day }\end{array}$ & $\begin{array}{l}\text { Banking } \\
\text { crisis } \\
\text { dummy }\end{array}$ & $\begin{array}{l}\text { Currency } \\
\text { crisis } \\
\text { dummy }\end{array}$ & $\begin{array}{l}\text { Debt crisis } \\
\text { dummy }\end{array}$ & $\begin{array}{l}\text { GDP per } \\
\text { capita } \\
\text { (PPP) }\end{array}$ & $\begin{array}{l}\text { Trade } \\
\text { Openness Polity }\end{array}$ & $\begin{array}{ll}\text { Governme } & \\
\text { nt } & \\
\text { Expenditu } \\
\text { re Inflation }\end{array}$ \\
\hline
\end{tabular}

Poverty Gap at 1.25 USD a day Poverty ratio at 1.25 USD a day

Poverty ratio at 2 USD a day

Poverty Gap at 2 USD a day

Banking crisis dummy

Currency crisis dummy

Debt crisis dummy

GDP per capita (PPP)

Trade Openness

Polity

Government Expenditure

\subsection{0}

0.9558001 .000000

$\begin{array}{lll}0.863000 & 0.962100 & 1.000000\end{array}$

$\begin{array}{llll}0.966900 & 0.996500 & 0.962200 & 1.000000\end{array}$

$\begin{array}{lllll}0.027600 & -0.012500 & -0.023700 & -0.001100 & 1.000000\end{array}$

$\begin{array}{lllllll}0.102500 & 0.086400 & 0.074400 & 0.091300 & 0.016000 & 1.000000\end{array}$

$\begin{array}{lllllll}-0.024500 & -0.019500 & -0.008500 & -0.018000 & 0.112800 & 0.207800 & 1.000000\end{array}$

$\begin{array}{lllllllll}-0.589800 & -0.680500 & -0.773600 & -0.694800 & 0.019600 & -0.062700 & -0.010900 & 1.000000\end{array}$

$\begin{array}{lllllllll}-0.219800 & -0.271500 & -0.287300 & -0.265700 & 0.064200 & -0.087900 & 0.032800 & 0.167400 & 1.000000\end{array}$

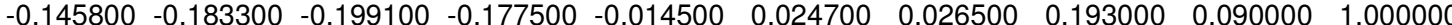

$\begin{array}{lllllllllll}-0.057000 & -0.127400 & -0.200800 & -0.129200 & 0.011900 & -0.001500 & -0.012800 & 0.190000 & 0.235200 & -0.041300 & 1.000000\end{array}$

Inflation

$\begin{array}{lllllllllllll}-0.036800 & -0.056500 & -0.065600 & -0.052400 & 0.054000 & 0.173300 & 0.031600 & 0.066400 & -0.103300 & 0.030700 & 0.035000 & 1.000000\end{array}$


Table A3 - Fixed effects regression results while using Poverty headcount ratio at 2 USD a day

\begin{tabular}{|c|c|c|c|c|c|c|c|}
\hline & Model 1 & Model 2 & Model 3 & Model 4 & Model 5 & Model 6 & Model 7 \\
\hline Banking crisis & $1.81(1.47)$ & & & $1.55(1.48)$ & $1.48(1.50)$ & & $1.38(1.53)$ \\
\hline Banking crisis (lagged) & $-0.31(1.47)$ & & & $-1.11(1.55)$ & $-0.64(1.52)$ & & $-1.34(1.67)$ \\
\hline Banking crisis (second lag) & $0.29(1.66)$ & & & $-0.012(1.87)$ & $0.18(1.69)$ & & $-0.18(1.87)$ \\
\hline Currency crisis & & $4.30^{*}(2.61)$ & & $4.36 *(2.63)$ & & $3.90(2.73)$ & $3.99(2.75)$ \\
\hline Currency crisis (lagged) & & $3.36 * *(1.67)$ & & $3.73 * *(1.72)$ & & $3.37 * *(1.73)$ & $3.50 * *(1.77)$ \\
\hline Currency crisis (second lag) & & $-1.43(1.78)$ & & $-1.36(1.71)$ & & $-1.76(1.74)$ & $-1.72(1.76)$ \\
\hline Debt crisis & & & $6.96(4.52)$ & & $6.63(4.67)$ & $4.77(4.27)$ & $4.37(4.40)$ \\
\hline Debt crisis (lagged) & & & $2.25(3.30)$ & & $2.60(3.50)$ & $1.53(3.55)$ & $2.15(3.73)$ \\
\hline Debt crisis (second lag) & & & $2.31(2.94)$ & & $2.36(3.06)$ & $3.21(3.19)$ & $3.32(3.30)$ \\
\hline Openness & $-0.038(0.025)$ & $-0.049 *(0.025)$ & $-0.044 *(0.025)$ & $-0.048 *(0.025)$ & $-0.044 *(0.025)$ & $-0.051 * *(0.025)$ & $-0.051 * *(0.025)$ \\
\hline Polity IV & $-0.018(0.022)$ & $-0.020(0.021)$ & $-0.010(0.021)$ & $-0.023(0.021)$ & $-0.012(0.022)$ & $-0.016(0.021)$ & $-0.019(0.021)$ \\
\hline Log of GDP per capita & $-21.87 * * *(2.52)$ & $-20.37 * * *(2.62)$ & $-21.45 * * *(2.53)$ & $-20.58 * * *(2.63)$ & $-21.61 * * *(2.53)$ & $-20.42 * * *(2.61)$ & $-20.61 * * *(2.63)$ \\
\hline Government expenditure & $-0.28 *(0.16)$ & $-0.24(0.16)$ & $-0.26(0.16)$ & $-0.024 *(.016)$ & $-0.26 *(0.16)$ & $-0.23(0.16)$ & $-0.23(0.17)$ \\
\hline Inflation & $-0.67(0.89)$ & $1.22(0.92)$ & $-0.66(0.92)$ & $-1.27(0.99)$ & $-0.73(0.98)$ & $-1.27(0.93)$ & $-1.29(0.99)$ \\
\hline Number of observations & 417 & 417 & 417 & 417 & 417 & 417 & 417 \\
\hline Number of groups & 90 & 90 & 90 & 90 & 90 & 90 & 90 \\
\hline
\end{tabular}

Note: Standard errors are reported in parentheses. * indicates significance at 10 percent, ${ }^{\star \star}$ indicates significance at 5 percent, ${ }^{\star \star \star}$ indicates significance at 1 percent level of significance respectively 
Table A4 - Fixed effects regression results while using Poverty Gap at 2 USD a day

\begin{tabular}{|c|c|c|c|c|c|c|c|}
\hline & Model 1 & Model 2 & Model 3 & Model 4 & Model 5 & Model 6 & Model 7 \\
\hline Banking crisis & $2.05 *(1.12)$ & & & $1.91 *(1.12)$ & $1.90 *(1.14)$ & & $1.87(1.14)$ \\
\hline Banking crisis (lagged) & $-0.82(0.90)$ & & & $-1.31(0.99)$ & $-1.020(0.96)$ & & $-1.44(1.87)$ \\
\hline Banking crisis (second lag) & $-0.23(0.70)$ & & & $-0.48(0.91)$ & $-0.24(0.71)$ & & $-0.54(0.81)$ \\
\hline Currency crisis & & $3.39 *(1.75)$ & & $3.47^{* *}(1.76)$ & & $3.24 *(1.85)$ & $3.36 *(1.85)$ \\
\hline Currency crisis (lagged) & & $1.90 *(1.14)$ & & $2.07 *(1.15)$ & & $1.82(1.17)$ & $1.99 *(1.18)$ \\
\hline Currency crisis (second lag) & & $-0.44(0.98)$ & & $-0.30(1.01)$ & & $-0.52(1.011)$ & $-0.43(1.03)$ \\
\hline Debt crisis & & & $3.29(2.54)$ & & $2.83(2.69)$ & $1.74(2.31)$ & $1.19(2.47)$ \\
\hline Debt crisis (lagged) & & & $0.97(1.49)$ & & $1.50(1.58)$ & $0.39(1.77)$ & $1.05(1.79)$ \\
\hline Debt crisis (second lag) & & & $0.42(1.45)$ & & $0.59(1.52)$ & $0.87(1.53)$ & $1.07(1.60)$ \\
\hline Openness & $-0.032^{*}(0.016)$ & $-0.038 * *(0.016)$ & $-0.036 * *(0.017)$ & $-0.038 * *(0.016)$ & $-0.036 * *(0.016)$ & $-0.039 * *(0.017)$ & $-0.039 * *(0.017)$ \\
\hline Polity IV & $-0.020(0.016)$ & $-0.012(0.017)$ & $-0.015(0.016)$ & $-0.022(0.017)$ & $-0.017(0.016)$ & $-0.018(0.016)$ & $-0.020(0.016)$ \\
\hline Log of GDP per capita & $-10.75^{* * *}(1.70)$ & $-9.69 * * *(1.83)$ & $-10.33 * * *(1.74)$ & $-9.94 * * *(1.80)$ & $-10.59 * * *(1.72)$ & $-9.75 * * *(1.80)$ & $-9.94^{* * *}(1.82)$ \\
\hline Government expenditure & $-0.017(0.12)$ & $0.006(0.11)$ & $-0.007(0.11)$ & $0.008(0.11)$ & $-0.007(0.12)$ & $0.008(0.11)$ & $0.016(0.12)$ \\
\hline Inflation & $0.30(0.73)$ & $-0.068(0.67)$ & $0.35(0.70)$ & $-0.12(0.70)$ & $0.29(0.74)$ & $-0.081(0.67)$ & $-0.12(0.71)$ \\
\hline Number of observations & 417 & 417 & 417 & 417 & 417 & 417 & 417 \\
\hline Number of groups & 90 & 90 & 90 & 90 & 90 & 90 & 90 \\
\hline
\end{tabular}

Note: Standard errors are reported in parentheses. ${ }^{*}$ indicates significance at 10 percent, ${ }^{* *}$ indicates significance at 5 percent, ${ }^{* * *}$ indicates significance at 1 percent level of significance respectively 


\section{APPENDIX 3}

Table A1 - Fixed effects regression results while using Poverty Gap at 1.25 USD a day as a dependent variable

\begin{tabular}{|c|c|c|c|c|c|c|c|}
\hline & Model 1 & Model 2 & Model 3 & Model 4 & Model 5 & Model 6 & Model 7 \\
\hline Banking crisis & $2.830^{* *}(1.195)$ & & & $2.97^{* * *}(1.13)$ & $2.82^{* *}(1.19)$ & & $2.97^{* *}(1.13)$ \\
\hline Banking crisis (lagged) & $-0.075(0.509)$ & & & $-0.601(0.615)$ & $-0.068(0.510)$ & & $-0.60(0.61)$ \\
\hline Banking crisis (second lag) & $0.153(0.246)$ & & & $-0.209(0.417)$ & $0.28(0.31)$ & & $-0.05(0.46)$ \\
\hline Currency crisis & & $1.680^{* *}(1.47)$ & & $1.89{ }^{* *}(0.88)$ & & $1.66 *(0.85)$ & $1.85^{* *}(0.88)$ \\
\hline Currency crisis (lagged) & & $.796(.516)$ & & $0.93^{*}(0.53)$ & & $0.91(0.54)$ & $1.02^{*}(0.55)$ \\
\hline Currency crisis (second lag) & & $-0.024(0.465)$ & & $0.099(0.474)$ & & $0.028(0.47)$ & $0.13(0.47)$ \\
\hline Debt crisis & & & $1.27^{\star}(0.70)$ & & $1.33^{*}(0.69)$ & $0.64(0.67)$ & $0.61(0.67)$ \\
\hline Debt crisis (lagged) & & & $0.29(0.44)$ & & $0.32(0.49)$ & $0.02(0.58)$ & $0.12(0.67)$ \\
\hline Debt crisis (second lag) & & & $0.07(0.37)$ & & $0.16(0.37)$ & $0.13(0.46)$ & $0.25(0.49)$ \\
\hline Openness & $-0.026^{*}(0.013)$ & $-0.030^{* *}(0.014)$ & $-0.031^{* *}(0.014)$ & $-0.028 * *(0.013)$ & $-0.026 *(0.013)$ & $-0.031 * *(0.014)$ & $-0.029 *(0.013)$ \\
\hline Polity IV & $-0.015(0.015)$ & $-0.016(0.015)$ & $-0.016(0.015)$ & $-0.015(0.015)$ & $-0.015(0.015)$ & $-0.016(0.016)$ & $-0.016(0.015)$ \\
\hline Log of GDP per capita & $-5.306^{* * *}(1.443)$ & $-4.547^{\star \star \star}(1.537)$ & $-4.96 * * *(1.49)$ & $-4.81 * * *(1.48)$ & $-5.27 * * *(1.45)$ & $-4.43 * * *(1.56)$ & $-4.72 * * *(1.50)$ \\
\hline Government expenditure & $0.069(0.109)$ & $0.094(0.107)$ & $0.090(0.107)$ & $0.083(0.108)$ & $0.073(0.108)$ & $0.100(0.107)$ & $0.08(1.01)$ \\
\hline Inflation & $0.578(0.649)$ & $0.527(0.610)$ & $0.786(0.652)$ & $0.32(0.61)$ & $0.57(0.65)$ & $0.53(0.62)$ & $0.32(0.65)$ \\
\hline Number of observations & 417 & 417 & 417 & 417 & 417 & 417 & 417 \\
\hline Number of groups & 90 & 90 & 90 & 90 & 90 & 90 & 90 \\
\hline
\end{tabular}

Note: Standard errors are reported in parentheses. ${ }^{*}$ indicates significance at 10 percent, ${ }^{* *}$ indicates significance at 5 percent, ${ }^{* * *}$ indicates significance at 1 percent level of significance respectively 
Table A2 - Fixed effects regression results while using Poverty Headcount ratio at 1.25 USD a day

\begin{tabular}{|c|c|c|c|c|c|c|c|}
\hline & Model 1 & Model 2 & Model 3 & Model 4 & Model 5 & Model 6 & Model 7 \\
\hline Banking crisis & $3.050^{* *}(1.396)$ & & & $3.25^{\star *}(1.34)$ & $3.044^{\star *}(1.41)$ & & $3.25^{\star *}(1.35)$ \\
\hline Banking crisis (lagged) & $.686(1.133)$ & & & $-0.133(1.21)$ & $0.70(1.13)$ & & $-0.13(1.22)$ \\
\hline Banking crisis (second lag) & $0.265(0.622)$ & & & $-0.27(0.91)$ & $0.56(0.81)$ & & $0.03(1.03)$ \\
\hline Currency crisis & & $2.845 *(1.558)$ & & $3.03 *(1.59)$ & & $2.81 *(1.53)$ & $2.95^{\star}(1.58)$ \\
\hline Currency crisis (lagged) & & $1.208(.740)$ & & $1.32^{*}(0.764)$ & & $1.43^{*}(0.80)$ & $1.50^{*}(0.81)$ \\
\hline Currency crisis (second lag) & & $-0.389(.894)$ & & $-0.253(0.909)$ & & $-0.28(0.90)$ & $-0.17(0.91)$ \\
\hline Debt crisis & & & $3.024^{\star *}(1.41)$ & & $3.01^{* *}(1.41)$ & $1.96(1.27)$ & $1.95(1.27)$ \\
\hline Debt crisis (lagged) & & & $0.36(1.06)$ & & $0.21(1.12)$ & $-0.02(1.19)$ & $-0.06(1.28)$ \\
\hline Debt crisis (second lag) & & & $0.76(0.91)$ & & $0.86(0.94)$ & $1.01(1.02)$ & $1.15(1.05)$ \\
\hline Openness & $-0.037 *(0.021)$ & $-0.043^{* *}(0.021)$ & $-0.041 *(0.022)$ & $-0.040 * *(0.021)$ & $-0.038 *(0.022)$ & $-0.045 * *(0.022)$ & $-0.042^{*}(0.021)$ \\
\hline Polity IV & $-0.028(0.023)$ & $-0.030(0.023)$ & $-0.029(0.023)$ & $-0.030(0.023)$ & $-0.029(0.023)$ & $-0.031(0.024)$ & $-0.031(0.023)$ \\
\hline Log of GDP per capita & $-15.73^{* * *}(2.43)$ & $-14.80 * * *(2.509)$ & $-15.37^{* * *}(2.42)$ & $-15.07 * * *(2.50)$ & $-15.64 * * *(2.43)$ & $-14.58 * * *(2.52)$ & $-14.888^{\star * *}(2.52)$ \\
\hline Government expenditure & $-0.088(0.151)$ & $-0.054(0.147)$ & $-0.057(0.146)$ & $-0.07(0.14)$ & $-0.081(0.14)$ & $-0.044(0.144)$ & $-0.60(0.14)$ \\
\hline Inflation & $-0.185(1.00)$ & $-0.312(0.950)$ & $0.109(0.97)$ & $-0.51(0.99)$ & $-0.17(1.02)$ & $-0.29(0.96)$ & $-0.55(1.00)$ \\
\hline Number of observations & 417 & 417 & 417 & 417 & 417 & 417 & 417 \\
\hline Number of groups & 90 & 90 & 90 & 90 & 90 & 90 & 90 \\
\hline
\end{tabular}

Note: Standard errors are reported in parentheses. ${ }^{*}$ indicates significance at 10 percent, ${ }^{* *}$ indicates significance at 5 percent, ${ }^{* * *}$ indicates significance at 1 percent level of significance respectively 
Table A3 - Fixed effects regression results while using Poverty Gap at 2 USD a day

\begin{tabular}{|c|c|c|c|c|c|c|c|}
\hline & Model 1 & Model 2 & Model 3 & Model 4 & Model 5 & Model 6 & Model 7 \\
\hline Banking crisis & $2.67 * *(1.13)$ & & & $2.82^{* * *}(1.07)$ & $2.66^{* *}(1.14)$ & & $2.82^{* *}(1.08)$ \\
\hline Banking crisis (lagged) & $0.432(0.78)$ & & & $-0.212(0.86)$ & $0.44(0.77)$ & & $-0.21(0.87)$ \\
\hline Banking crisis (second lag) & $0.27(0.40)$ & & & $-0.145(0.63)$ & $0.49(0.52)$ & & $0.09(0.72)$ \\
\hline Currency crisis & & $2.128 *(1.166)$ & & $2.28^{*}(1.19)$ & & $2.10 *(1.15)$ & $2.22 *(1.19)$ \\
\hline Currency crisis (lagged) & & $1.030 *(.581)$ & & $1.12 *(0.59)$ & & $1.19^{*}(0.61)$ & $1.26^{* *}(0.62)$ \\
\hline Currency crisis (second lag) & & $-0.361(0.687)$ & & $-0.24(0.701)$ & & $-0.28(0.69)$ & $-0.19(0.70)$ \\
\hline Debt crisis & & & $2.20^{\star *}(1.06)$ & & $2.27^{* *}(1.05)$ & $1.40(0.94)$ & $1.39(0.94)$ \\
\hline Debt crisis (lagged) & & & $0.50(0.75)$ & & $0.42(0.81)$ & $0.21(0.86)$ & $0.22(0.93)$ \\
\hline Debt crisis (second lag) & & & $0.57(0.60)$ & & $0.65(0.62)$ & $0.78(0.70)$ & $0.88(0.73)$ \\
\hline Openness & $-0.031 *(0.016)$ & $-0.036 * *(0.016)$ & $-0.034 * *(0.016)$ & $-0.034 * *(0.015)$ & $-0.032 * *(0.015)$ & $-0.037 * *(0.016)$ & $-0.035 * *(0.016)$ \\
\hline Polity IV & $-0.017(0.016)$ & $-0.019(0.017)$ & $-0.018(0.016)$ & $-0.019(0.016)$ & $-0.018(0.016)$ & $-0.020(0.016)$ & $-0.020(0.016)$ \\
\hline Log of GDP per capita & $-10.74 * * *(1.70)$ & $-9.96 * * *(1.77)$ & $-10.43 * * *(1.722)$ & $-10.20 * * *(1.75)$ & $-10.68 * * *(1.70)$ & $-9.80 * * *(1.78)$ & $-10.06 * * *(1.76)$ \\
\hline Government expenditure & $-0.030(0.118)$ & $-0.002(0.115)$ & $-0.005(0.115)$ & $-0.015(0.11)$ & $-0.024(0.116)$ & $0.005(0.114)$ & $-0.008(0.116)$ \\
\hline Inflation & $0.149(0.118)$ & $0.071(0.682)$ & $0.39(0.71)$ & $-0.14(0.70)$ & $0.15(0.73)$ & $0.081(0.69)$ & $-0.13(0.71)$ \\
\hline Number of observations & 417 & 417 & 417 & 417 & 417 & 417 & 417 \\
\hline Number of groups & 90 & 90 & 90 & 90 & 90 & 90 & 90 \\
\hline
\end{tabular}

Note: Standard errors are reported in parentheses. ${ }^{*}$ indicates significance at 10 percent, ${ }^{* *}$ indicates significance at 5 percent, ${ }^{* * *}$ indicates significance at 1 percent level of significance respectively 
Table A4 - Fixed effects regression results while using Poverty headcount ratio at 2 USD a day

\begin{tabular}{|c|c|c|c|c|c|c|c|}
\hline & Model 1 & Model 2 & Model 3 & Model 4 & Model 5 & Model 6 & Model 7 \\
\hline Banking crisis & $2.047(1.26)$ & & & $2.19^{*}(1.27)$ & $2.03(1.28)$ & & $2.18^{*}(1.30)$ \\
\hline Banking crisis (lagged) & $1.58(1.48)$ & & & $0.69(1.55)$ & $1.60(1.48)$ & & $0.68(1.58)$ \\
\hline Banking crisis (second lag) & $0.64(.82)$ & & & $0.11(1.17)$ & $1.00(1.03)$ & & $0.50(1.32)$ \\
\hline Currency crisis & & $2.865(1.928)$ & & $2.87(1.99)$ & & $2.83(1.90)$ & $2.78(1.98)$ \\
\hline Currency crisis (lagged) & & $1.719 *(.989)$ & & $1.71 *(1.01)$ & & $1.96 *(1.05)$ & $1.94^{*}(1.06)$ \\
\hline Currency crisis (second lag) & & $-1.300(1.488)$ & & $-1.23(1.50)$ & & $-1.18(1.50)$ & $-1.13(1.51)$ \\
\hline Debt crisis & & & $4.43^{\star *}(1.97)$ & & $4.51^{\star *}(1.97)$ & $3.33^{*}(1.73)$ & $3.38^{*}(1.74)$ \\
\hline Debt crisis (lagged) & & & $1.16(1.66)$ & & $0.83(1.70)$ & $0.83(1.74)$ & $0.67(1.84)$ \\
\hline Debt crisis (second lag) & & & $2.03(1.32)$ & & $2.06(1.35)$ & $2.60^{*}(1.55)$ & $2.67^{\star}(1.58)$ \\
\hline Openness & $-0.037(0.025)$ & $-0.044 *(0.025)$ & $-0.040(0.025)$ & $-0.042 *(0.025)$ & $-0.038 *(0.025)$ & $-0.046 * *(0.025)$ & $-0.044 *(0.025)$ \\
\hline Polity IV & $-0.017(0.021)$ & $-0.021(0.021)$ & $-0.018(0.022)$ & $-0.021(0.021)$ & $-0.018(0.021)$ & $-0.023(0.021)$ & $-0.022(0.021)$ \\
\hline Log of GDP per capita & $-21.83^{* * *}(2.53)$ & $-21.018^{* * *}(2.522)$ & $-21.63^{* * *}(2.49)$ & $-21.19 * * *(2.53)$ & $-21.71 * * *(2.51)$ & $-20.77^{* * *}(2.52)$ & $-20.94 * * *(2.54)$ \\
\hline Government expenditure & $-0.301 *(0.163)$ & $-0.266^{*}(0.16)$ & $-0.27^{\star}(0.15)$ & $-0.028 *(0.016)$ & $-0.29 *(0.15)$ & $-0.25(0.17)$ & $-0.27^{\star}(0.16)$ \\
\hline Inflation & $-0.84(0.96)$ & $-.973(0.923)$ & $-0.53(0.93)$ & $-1.18(0.96)$ & $-0.82(0.98)$ & $-0.94(0.93)$ & $-1.16(0.97)$ \\
\hline Number of observations & 417 & 417 & 417 & 417 & 417 & 417 & 417 \\
\hline Number of groups & 90 & 90 & 90 & 90 & 90 & 90 & 90 \\
\hline
\end{tabular}

Note: Standard errors are reported in parentheses. ${ }^{*}$ indicates significance at 10 percent, ${ }^{* *}$ indicates significance at 5 percent, ${ }^{* * *}$ indicates significance at 1 percent level of significance respectively 
